\section{Stakeholders or Shareholders? Board members' personal values and corporate identity}

\author{
Edson Ricardo Barbero \\ Alvares Penteado Foundation School of Commerce (Fecap), \\ Master Program in Business, São Paulo, SP, Brazil \\ Marcello Marchiano \\ Nove de Julho University (Uninove), Graduate Program in \\ Management, São Paulo, SP, Brazil
}

Received on

02/24/2016

Approved on

06/17/2016

Responsible editor:

$\mathrm{PhD}$. Leire San-Jose

Evaluation process:

Double Blind Review

\begin{abstract}
Purpose - This article diagnoses the relationship between the value priorities of board members in Brazil and their companies' identities trending towards stakeholders or shareholders. The paper tested five hypotheses referring to the fact that board members of profitoriented companies are more individualistic, while board members of stakeholder-oriented companies tend to be more collectivist.
\end{abstract}

Design/methodology/approach - A survey was carried out through the Schwartz (1992) values inventory with 74 board members in Brazil. The Brazilian Corporate Sustainability Index (ISE) was considered a proxy for stakeholder orientation. The Mann-Whitney test was used in order to verify if the two independent samples were drawn from populations with equal averages.

Findings - In partial consonance with previous research, the board members of stakeholder-oriented companies - those participating in the Corporate Sustainability Index - held less individualistic values. However, for individualistic motivational types, only Stimulation and Hedonism were more frequent in companies not participating in the ISE index.

Originality/value - This result amplifies the predictive power of individual values and complements the work of Adams, Licht and Sagiv (2011), which experimentally studied the same relationship within individual choices and in a controlled situation. This article enhances the theory by incorporating the organizational level into the debate. The results suggest that other factors also influence pro-shareholder or pro-stakeholder corporate orientation.

Keywords - Axiological priorities; stakeholders; board of directors; individual values.

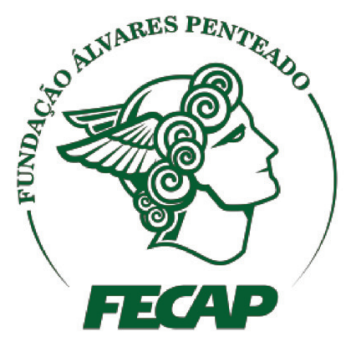

Review of Business Management 


\section{Introduction}

This paper seeks to explain the relationship between the individual values of board members and their companies' identities - whether proshareholders or pro-other stakeholders. To Schwartz (1992), individual values bring together various scientific fields interested in human behavior and are "criteria people use to select and justify actions" (p. 1). In parallel, Brickson (2005) reveals that corporate identity is a set of symbols, behaviors and processes that make an organization different from others that are similar to it. This author reveals that organizational identities can be either individualist or collectivist and that "the relationship with stakeholders constitute the prominent feature of organizational identity" (Brickson, 2005, p. 576). In this respect, organizations that tend towards collectivism are the ones which see themselves as members of society as a whole and which guide their decisions to multiple stakeholders (Bartlett, McDonald \& Pini, 2015).

Adams et al. (2011) closely analyzed the abovementioned relationship by means of a quasiexperimental research in the individual context of decision makers. They found that there are positive correlations between collectivist values and decisions in favor of stakeholders who are not owners. However, those authors only studied the individual level of decisions, since they exposed directors to "laboratory" situations and measured the correlations between the decisions they made and their personal values. The conclusions of Adams et al. (2011) emphasize to the existence of the explanatory power of values in directors' trends towards exclusively to shareholders or towards other stakeholders.

From the research of Adams et al. (2011), therefore, a question arises: would the results be the same if the aforementioned relationship were analyzed within the context of an organization as a whole, and in a real (not experimental) situation? Thus, there is still a theoretical gap concerning the existence of relationships between the axiological profiles of business leaders and their companies' pro-shareholder or pro-stakeholder orientation. It is important to answer this question, because businessmen do in fact make decisions not only according to their personal convictions, but according to their context. To Jones et al. (2007), "although the focus of Stakeholder Theory has been managers as anonymous decision makers, these businessmen are deeply influenced by organizational context" (p. 137).

This study fills this gap. Instead of evaluating the individual decisions of board members, it identifies the greater or lesser presence of certain types of motivation in the board members of stakeholder-oriented companies. The insertion of the domain of entire organization has theoretical and practical relevance. From a theoretical perspective, no previous studies have undertaken research on individual values and corporate identity in favor of shareholders or other stakeholders. As well as Adams et al. (2011), who did not include organizational dimensions in their analysis, as mentioned, empirical studies show that values are related to creativity (Dollinger, Burke, \& Gump, 2007), to reaction to organizational change (Sverdlik \& Oreg, 2009), to cooperation and to competition (Sagiv, Sverdlik, \& Schwartz, 2011).

In practical terms, understanding of this relationship sheds relevant light on the selection of board members who are most appropriate for a company. Recent literature indicates that leaders who harbor greater identification with the values of a company tend to be better stewards of the organization's interests (Boivie, Lange, McDonald \& Wespahl, 2011). This paper contributes, finally, to the empirical understanding of an important public (board members), since Brazilian studies such as Bruére, Mendes-da-Silva and Santos (2007) did not advance as to the question of personal values.

Also as justification, we point out that many authors from the Stakeholder Theory have advocated the need to understand human complexity as a foundation for understanding 
the relationship between a company and its external stakeholders (Freeman \& Phillips, 2002; Bosse, Phillips \& Harrison, 2009). Bridoux and Stoelhorst (2014) point out that empirical evidence on human motivational heterogeneity suggests improvements to the Stakeholder Theory. Freeman and Phillips (2002) indicate that it is necessary to understand the topic beyond the default assumption that individuals only selfishly strive for their own results; they also warn us that "it is necessary to question oneself as to how values are created in a world where individuals have complex motivations" (p. 334). To Jones, Felps and Bligley (2007), finally, the convergent topic in Business Ethics is precisely the opposition between values which consider the interests of others and, in the opposite direction, those which consider only individual interests.

From these findings and justifications, this article's research problem emerges: What are the differences, in terms of individual values, between the board members of stakeholderoriented companies and those belonging to other publicly traded companies? To answer this question, we carried out a survey with 74 board members from publicly traded companies operating in Brazil, and used the company's presence in BM\&FBovespa's (São Paulo Stock Exchange) Corporate Sustainability Index as a proxy for corporate identity. As we will explain later on, this index is suitable for measuring this important aspect of the identity of a company: the relationship with its external publics (Brickson, 2005).

As main results, we identified the greater presence of individualistic board members in companies listed in the São Paulo Stock Exchange which are not part of the Corporate Sustainability Index (ISE). Moreover, 18 individual values from Schwartz's theory (1992) presented themselves as different between companies focused on stakeholders (ISE) and other companies listed in BM\&FBovespa. In addition, motivational types Stimulation and Hedonism presented lower axiological priority among board members working in stakeholder-oriented companies. These findings reinforce - in part - the hypotheses of this article. As will be examined in more detail later, there are differences as to the findings of Adams et al. (2011). In this regard, specially, this article includes discussions about the Hedonism motivational type. The next item presents this debate's theoretical framework and establishes research hypotheses. After that, we present and discuss the results.

\section{Theoretical framework and formulation of hypotheses}

\section{I Origins and assumptions of the Stakeholder Theory}

The theoretical debate about the relationship of a company with its external public is largely dichotomous. Fundamentally, it is divided in two opposing currents: the Theory of the Firm and the Stakeholder Theory. According to Boaventura, Cardoso, Silva and Silva (2009), the former's origins are in the eighteenth century, but its main work is in Friedman (1962). This conceptual line advocates that managers should make all decisions focused on increasing the long-term value of a company (Jensen, 2001). The Stakeholder Theory is more recent - Freeman (1984) is its seminal work - and considers that companies should coordinate the interests of various stakeholders. Friedman (1962) states that businessmen are the principal's agents and that their primary responsibility is to serve its interests.

While those who defend the Theory of the Firm indicate a role that is confined to maximizing value for shareholders, other critics consider that this theory has little empirical support (Clarke, 1998), advocating a more comprehensive role for companies. Davis, Schoorman and Donaldson (1997) point out other possibilities for the agency conflict, arguing that taking on an assumption of conflict is not reasonable for all types of men. While those who defend the theory of the firm presuppose a utilitarian trend, different theoretical 
currents argue against this claim, suggesting other factors as drivers of the decision-making process.

The Stakeholder Theory sees organizations as a collection of groups whose objectives must be coordinated by managers (Freeman, 1984). The classic definition of stakeholder is "any group or individual who can affect or is affected by the achievement of the organization's objectives" (Freeman, 1984, p. 46). In this sense, "a more comprehensive and ambitious understanding of the concept of stakeholder is a redefinition of organizations and of how they should be defined" (Friedman \& Phillips, 2002, p. 1).

According to Laplume, Sonpar and Litz (2008, p. 1153), "the Stakeholder Theory is timely yet adolescent, controversial yet important." Timely because of the prevalence of corporations and of several ethical scandals; adolescent because empirical validation is still incipient in many of its propositions; and controversial, because it touches controversial issues. Margolis and Walsh (2003) argue that, because the Stakeholder Theory incites differences concerning deeply held values, its supporters and detractors tend not to converge. It is clear, too, that the increasing prominence of the Stakeholder Theory occurred because it is a proposition that moves people, also due to the emotional resonance that its assumptions generate in many individuals (Weick, 1999). The Stakeholder Theory, as well as its practice, therefore, seems to relate to people and to the ways in which they see the world. Hence the relevance of empirically connecting the conceptual framework of values and that which discusses the relationship of a company with its stakeholders.

Given these elements, we are led to realize that companies with different characteristics also must have equally different orientations with respect to the relationship with their publics. To Bridoux and Stoelhorst (2014), companies can develop relationships based on bargaining power (arms-length approach) or, oppositely, relationships based on reciprocity and justice. Mitchell, Agle and Wood (1997) understand that the relationship between the company and its publics is mediated by the power and legitimacy of these stakeholders and by the urgency of their demands. Harrison, Bosse and Phillips (2010) call this company relationship type based on harmonious relations as "managing for stakeholders". According to these authors, a company with such an approach "allocates more resources to meet the needs and demands of its stakeholders than necessary to simply maintain their participation" (Harrison et al., 2010, p. 58). In essence, these authors explain that a better relationship with stakeholders leads them to share their utility functions and, thus, feed this good relationship by increasing company value (Harrison et al., 2010).

In the context of Organizational Theories, Brickson (2005) approaches the debate about orientation towards the plurality of publics or simply shareholders to the concept of Organizational Identity. To this author, companies can harbor three different orientations (individualistic, relational or collectivist) and the relationship with stakeholders is the supreme attribute of organizational identity (Brickson, 2005). We can observe, from the above discussion, the already manifest proximity between stakeholder theories and those focused on understanding human values. Hence, this is the next topic we are going to focus on theoretically; with greater emphasis, it presents the conceptual framework of Schwartz, on which the empirical work of this article is based. This topic also includes contributions that explain the mediation between individual values and a company's general guidelines. Harrison, Freeman and Abreu (2015, p. 866) assert that "stakeholders are basically moral".

\subsection{Values, shareholder or stakeholder orientation and intervening variables}

The theory of individual values was developed over almost three decades. According to Tamayo and Porto (2005), we have known since the early 1970s that it is possible to predict individual behavior based on the priorities that people give to their values. Rokeach (1973) 
addressed the predictability of human behavior based on values, and said that a person's values predict how he or she will behave. Rokeach (1973) defines value as a permanent belief in a specific model of conduct that is personally or socially adopted.

The great contribution of Schwartz (2005) was the identification of motivations that express these values, leading to dynamic relationships between values and their corresponding motivational types (Tamayo, 2007). Schwartz's theory proposes a model that establishes values as aspirations that aim to satisfy human needs, organized in ten motivational types. Schwartz (2005) proposes that the theory of values describes aspects that are common to all mankind. To this end, he identified a set of universal values, wherein motivational types were comprehensive and held meaning to various different cultures. These values can be organized in hierarchies, representing the preferences, choices and actions of individuals. The hierarchy of values is also known as the Axiological Priority. The ten motivational types identified by Schwartz (1992; 1994; 2005) are as follows:

a) Security: personal integrity, stability in society and of itself;

b) Conformity: share restriction that may violate social norms;

c) Tradition: respect and acceptance of the ideals and customs of the society;

d) Benevolence: promoting the well-being of intimates;

e) Universalism: tolerance and protection of people and nature;

f) Achievement: personal success through demonstrating competence;

g) Stimulation: excitement, novelty, change and challenge in life;

h) Hedonism: pleasure or sensual gratification for yourself;

i) Self-direction: independent thought and action;

j) Power: social status and dominance over people and resources.
The compatibility or conflict between dimensions should be observed. On the one hand, there is self-transcendence (universalism and benevolence), which is opposed to selfenhancement (power, achievement and hedonism). At the other end, there is openness to change (stimulation and self-direction), which is opposed to conservation (tradition, conformity and security). The dimensions are shown in Figure 1. The same pictorial structure is commonly used to present the results of empirical studies.

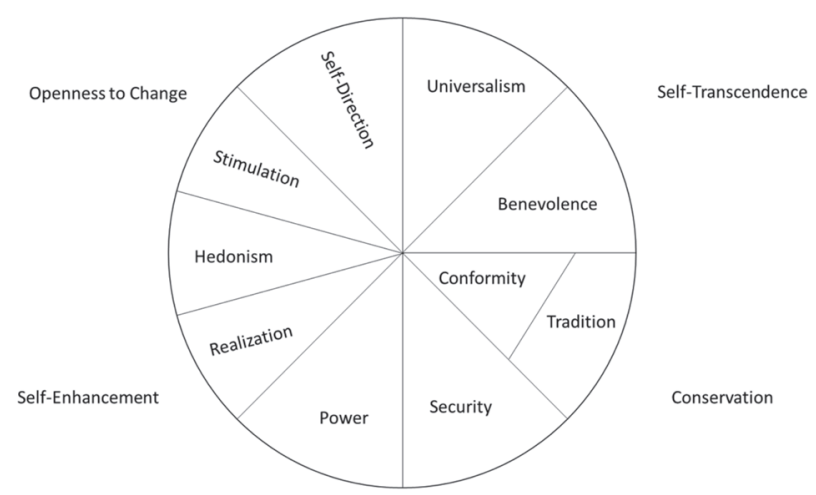

Figure 1. Theory of basic human values. Source: Adapted from Schwartz (2005, p. 143).

According to Schwartz (2005), the closer two motivational types are in Figure 1, the more similar their underlying motivations are. Also according to this author, the motivational types power, achievement, hedonism, stimulation and self-direction meet mainly individual interests. The motivational types universalism, tradition, security, conformity and benevolence meet collective interests. From these findings, the individualism x collectivism duality emerges; it will be crucial to understanding the results of this material. Triandis (1995) points to the relevance of this dichotomy, while indicating that people often do not manifest this bipolarity, and that specific circumstances define individuals' ultimate behavior. Among the various personal guidelines identified in literature, individualism and collectivism are probably some of the most useful constructs in assessing human values in an objective and systematic way (Lee \& Choi, 
2005). Individualism emphasizes self-sufficiency, prioritizes personal goals at the expense of group goals and gives greater importance to its own worldviews than to social norms (Triandis \& Gelfand, 1998). Collectivist values, on the other hand, emphasize interdependence and prioritize joint decisions (Triandis \& Gelfand, 1998).

Regarding the Stakeholder Theory, the value $\mathrm{x}$ managers' behavior relation has encouraged the contribution of Adams et al. (2011), who undertook quasi-experimental research exposing 628 Swedish company board members to vignettes that showed dilemmas between stakeholders and shareholders. The authors proposed the construct shareholderism, which measures the preference to distribute resources to shareholders. The authors exposed respondents to four situations (each with a different stakeholder) in which individuals had to point out their positions on a Likert agreement scale. As well as other analyses, Adams et al. (2011) came to the conclusions presented in Table 1.

\section{Table 1}

\section{Correlations identified by Adams et al. (2011)}

\begin{tabular}{lcc}
\hline $\begin{array}{l}\text { Motivational } \\
\text { Type }\end{array}$ & $\begin{array}{c}\text { Individualism (I) } \\
\text { Collectivism (C) }\end{array}$ & $\begin{array}{c}\text { Correlations with } \\
\text { shareholderism }\end{array}$ \\
\hline Conformity & C & $-0.11^{* *}$ \\
Tradition & C & $-0.11^{* *}$ \\
Benevolence & C & $-0.18^{* *}$ \\
Universalism & C & $-0.34^{* *}$ \\
Security & C & $-0.10^{*}$ \\
\hline Self-direction & I & $0.20^{* *}$ \\
Stimulation & I & $0.13^{* *}$ \\
Hedonism & I & 0.00 \\
Achievement & I & $0.34^{* *}$ \\
Power & I & $0.35^{* *}$ \\
\hline
\end{tabular}

Source: Modified from Adams et al. (2011, p.1342)** Significant at 0.01 and ${ }^{*}$ Significant at 0.05

In Table 1, the significant positive correlations between individualistic values (except hedonism) - which the authors call "entrepreneurial values" - and shareholderism can be observed. We can also observe the significant negative correlations between this same construct and collectivist values. The authors conclude that "these findings are generically consistent with the notion that shareholderism goes hand in hand with endorsing more entrepreneurial values" (Adams et al., 2011, p. 1343). The question of this article, however, includes the organizational domain, and not only the scope of individual decisions.

Jo Hatch and Cunliffe (2005, p. 5) point out that human beings, when making decisions, do not behave as if they were in a laboratory situation, "in which day-to-day influences are controlled." Organizational and institutional interventions ought to modify the similarity between individual decisions and the actual trends of organizations as a whole. One of these interventions, among others, is March's (1999) explanation for appropriateness, which indicates that, regardless of their personal inclinations, individuals tend to decide according to what their social group considers appropriate. The institutional environment also affects this relationship. Scott and Meyer (1991) point out that the regulatory environment, for example, modifies people's references. Hence, too, the urgent need to assess the values $\mathrm{x}$ stakeholder management in the way this article suggests.

\subsection{Conceptual model and research hypotheses}

Figure 2 presents the research model: the upper part of Figure 2 shows the level of organizational identity and the expected differences between dissimilar samples, using the circular structure of values advocated by Schwartz (1992). At the bottom, in the same Figure 2, correlations found by Adams et al. (2011) at the individual level are reinforced. We can observe the expectation that, in the motivational types at the right upper hand side of the illustration, ISE companies have significantly higher averages than the others. The exception is motivational type Hedonism, which showed no correlations in the research of Adams et al. (2011). We must also observe that this study will test the phenomenon represented at the top of Figure 2. The bottom of 
the figure only recalls the findings of Adams et al. that support the construction of hypotheses.

(2011), and is there to show part of the arguments

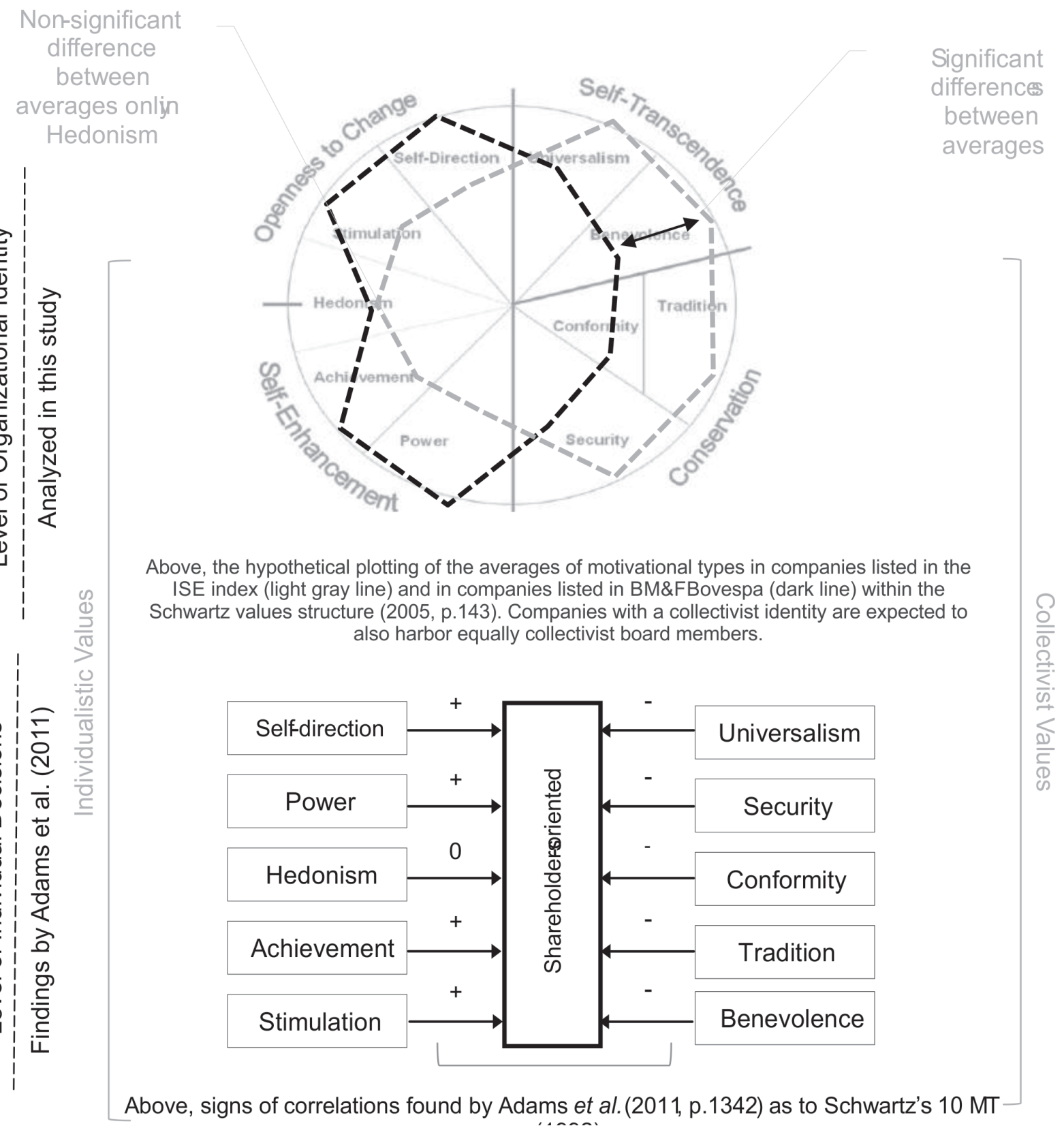

Figure 2. Conceptual research model. Top part of the figure is tested in this paper.

Several studies show that the personal attributes of corporate elites influence their behavior and, therefore, motivate their actions within the organizational context (Fiss \& Zajac, 2004; Hiller \& Hambrick, 2005). In parallel, as explained earlier, Schwartz's values theory (1992) points to 10 motivational types that, in their entirety, make up the structure of his theory. In his own theoretical framework, as in Schwartz (2005), the author points out that social groups oriented towards a given direction would, over time, tend to attract and retain individuals with a similar axiological profile. Moreover, Adams et al. (2011) found positive correlations between 
values considered "entrepreneurial" and decisions trending towards shareholders.

Few studies focused on relating the personal values of individuals and their business decisions. The first among these rare studies was carried out by Agle, Mitchell and Sonnenfeld (1999), who examined whether the personal values of head American businessmen (CEOs) were linked to the prominence of the various stakeholders involved. This study, based on Rokeach's scale value of items (1973) did not produce conclusive results.

The debate about the direction of corporate identity, whether favorable to the exclusive interests of shareholders or proposing coordination between all stakeholders, is still recent, and has not found definitive theoretical and practical support. What is that determines whether a company's identity tends more towards shareholders or stakeholders, after all? The role of the various types of shareholders also cannot be considered homogeneous, since institutional shareholders, governments and families have different cultural purposes and influences (Fiss \& Zajac, 2004). These influences entail specific purposes by the representatives of each type of shareholder, playing within organizations a favorable role to an exclusively pro-shareholder or broader model. As well as this diversity, the cultural environment in which the organization operates interferes with its social and environmental performance (Ringov \& Zollo, 2007), as well, as in the opposite direction, their own reputation and organizational legitimacy influence the attraction of the publics of a given company (Puncheva, 2008). A firm whose organizational identity favors stakeholders would tend also to attract heterogeneous publics to their relationships. This point to the hypotheses of this article, since it leads us to believe that pluralistic companies' board members would tend to be collectivist.

In addition to this debate, it is worth consulting literature as to board members. The controversy surrounding studies that concern board members appears especially when traits that interfere in the decision-making process are considered, such as self-esteem, desire to control, emotional stability and self-confidence (Hiller \& Hambrick, 2005). In this sense, individual values - since they are considered ways that affect individuals' perceptions of the external world (Meglino \& Ravlin, 1998) - can broaden the understanding of key business decisions. Verplanken and Holland (2002) stated that values lead to actions that are consistent with them. Regarding the relationship between the axiological profile of board members and their companies' trend towards stakeholders or shareholders, we expect significant differences between the values propounded by the board members of companies listed in BM\& FBovespa's ISE and those of other companies.

Since Adams et al. (2011) have already pointed out a relationship in the context of individual decisions in quasi-experimental research using correlational techniques, this study focuses on a broader organizational context, aiming to extend the theory on the subject within the scope of company's identity. We expect a greater presence of collectivist board members among companies with an equally collectivist identity. To reinforce the findings of Adams et al. (2011), the reason for this hypothesis is the fact that collectivist values highlight interdependence and prioritize joint decisions between individuals and their surroundings (Triandis \& Gelfand, 1998). Since we expect leaders to print their own values on their companies, and since these values significantly influence decisions (Keeney, 1992), we also anticipate that there is, therefore, adhesion between personal values and organizational identity.

In addition, the social function of values is simultaneously to motivate and control the behavior of the members of a certain group (Jones, Felps \& Bigley, 2007). Thus, companies that hold manifestly pro-stakeholder values are likely to attract and retain board members of an adherent profile. Kilmann, Saxton and Serpa (1986) point out that the selection of members of 
senior managerial bodies tends over time towards individuals adhering to the values propounded by a company. Suchman (1995) points out that the actions of an organization are considered legitimate when they correspond to the standards of the social group that surrounds them. Hence, also, the hypothetical adhesion between the values and the pro-shareholders or pluralistic organizational trend.

Thus, we present our hypotheses $\left(\mathrm{H}_{\mathrm{s}}\right)$ below. Hypotheses $\mathrm{H}_{1}$ and $\mathrm{H}_{2}$ deal with the agglutination of motivational types around the concepts of individualism and collectivism. Hypotheses $\mathrm{H}_{3}$ and $\mathrm{H}_{4}$ refer to each of the motivational types separately; $\mathrm{H}_{3}$ for individualistic types and $\mathrm{H}_{4}$ for collective types. Hypothesis $\mathrm{H}_{5}$ deals with the exception of motivational type Hedonism, which did not present any correlation to the study of Adams et al. (2011).

H1: Board members from stakeholderoriented companies (in the ISE index) present significantly lower individualism than those from other companies listed in BM\&FBovespa; H2: Board members from stakeholder-oriented companies (in the ISE index) present significantly higher collectivism than those from other companies listed in BMSFBovespa; H3: Board members from stakeholder-oriented companies (in the ISE index) present motivational types SelfDirection, Stimulation, Achievement and Power significantly lower than those from other companies listed in BM\&FBovespa; H4: Board members from stakeholderoriented companies (in the ISE index) present motivational types Security, Conformity, Tradition, Benevolence and Universalism significantly higher than those from other companies listed in BM\&FBovespa.

The hypothesis about motivational type Hedonism, which was an exception in the findings of Adams et al. (2011), is established as described below. According to Adams et al. (2011), the fact that Hedonism does not appear as correlated with the pro-shareholders trend comes from the Schumpeter theory, which suggests that entrepreneurial capitalists do not seek immediate pleasure from their actions. So, we do not expect any differences between samples with respect to this motivational type.

H5: Board members from stakeholderoriented companies (in the ISE index) present motivational type Hedonism equivalent to the board members of other companies listed on BM\&FBovespa.

\section{Methods}

This research was characterized as descriptive, with a quantitative approach and, from the perspective of its technical procedures, as a survey. It was a collection of primary data through the Schwartz inventory of SVI values (with its 60 items), adapted and validated in Brazil by Tamayo (2007). Questions were closedended, seeking to obtain judgment through a scale of varying degrees of intensity. The answers attributed an increasing degree of intensity, from -1 (totally opposite) to 7 (extremely important), to each of the statements on the SVI scale. As well as the SVI questionnaire, a question was included to capture the presence in the ISE index (proxy for the pro-stakeholder trend). The resulting Cronbach's alpha for the questionnaire containing 60 Schwartz values was 0.923 , therefore considered satisfactory. Cronbach's alphas for constructs individualism and collectivism were 0.839 and 0.841 , respectively (Favero et al., 2009). Figure 2 shows the model used for the study.

The Corporate Sustainability Index (ISE) was considered a proxy for the pro-stakeholder trend, since it is based on the following principles when including businesses: environmental balance, social justice, commitment to sustainability, fairness, transparency and accountability (BM\&FBovespa, 2015). While we understand the limitations of this index to effectively grasp the pro-stakeholder identity phenomenon, we considered ISE viable and convenient. This is 
because it is a criterion that is respected by the Corporate Governance community in Brazil, and selection for companies' inclusion in the ISE follows strict criteria; its Executive Council is made up of eleven independent institutions.

With regard to data processing, we initially found that it was not normally distributed through the Kolmogorov-Smirnov and ShapiroWilk $(\alpha \mathrm{p}<0.001)$ tests for both the 60 values and the 10 motivational types that group them. After finding that data was non-parametric, the Mann-Whitney test was applied in order to determine whether the two independent samples (ISE and non-ISE companies) were drawn from populations with the same averages (Favero et al., 2009). Thus, each of the hypotheses from $\mathrm{H}_{1}$ to $\mathrm{H}_{5}$ were dealt with statistically as follows: $\mathrm{H}_{\mathrm{o}}$ : there is no significant difference between the averages of groups of companies (null hypothesis) and $\mathrm{H}_{1}$ : there is a difference.

The questionnaire was sent to board members participating in the Brazilian Institute of Corporate Governance (Instituto Brasileiro de Governança Corporativa, IBGC). Based on IBGC (2011) data, that there are approximately 2,000 board members working in Brazil. This institution collaborated with the response, forwarding messages and encouraging members to answer. Only board members were allowed to answer the survey, and as so certain cases were excluded. The survey was made available to the entire IBGC database; 145 questionnaires were answered, leading, ultimately, to 121 valid questionnaires. However, we chose to analyze only data from the board members of companies whose shares are traded in BM\&FBovespa. This generated a sample of 74 board members. This data deletion occurred so that there would be better control of the sample - because nothing would indicate that unlisted companies would not be pro-stakeholder oriented, since they would not anyway be able to participate in the ISE index. Given the difficulty of access to board members, we considered this sample as a valid contribution to empirical studies on the subject in Brazil. The questionnaires were self-administered via internet, and data collection was carried out between February 24, 2014 and April 14, 2014.

\section{Results and DISCUSSion}

\section{I Contextualization of the universe and of the sample}

This study investigates the research problem in the context of public companies in Brazil. The Brazilian capital market is a reflection of the national business structure, with a strong concentration of capital in the hands of a few shareholders (Saito \& Dutra, 2002), and low independence of boards as to ownership structures (Guerra, 2009). This indicates the strong presence of controlling shareholders in boards. These features generate a specific context for analysis. Additionally, from a cultural point of view, when assessing the six dimensions proposed by Hofstede (1980) and comparing them to Sweden, the country of origin of the studies of Adams et al. (2011), we observe significant differences. Among these differences, we highlight the following: (i) acceptance of inequalities and hierarchy (69 in Brazil and 31 in Sweden), (ii) individualism (38 in Brazil and 71 in Sweden), indicating a more collectivist society in the Brazilian case, (iii) also much higher risk aversion in Brazil (76-29) and (iv) greater indulgence in Sweden (59 to 78). Both aspects, capital structure in Brazil and cultural differences, should be considered when evaluating results.

According to the Brazilian Institute of Corporate Governance, there are 2,647 board member positions available in Brazil (IBGC, 2011); from this availability, only $7.7 \%$ are women and the rest are men. Each man occupies an average 1.24 boards, and every woman, an average 1.30 boards. Thus, we can infer that there are approximately 2,000 board members working in Brazil. In all, 335 companies are listed in the various corporate governance levels of the BM\&FBovespa.

The sample of this study is made up exclusively of board members from companies 
operating in Brazil, and whose companies are listed in the São Paulo Stock Exchange (BM\&FBovespa). We excluded from analysis companies without shares traded in the São Paulo Stock Exchange. Most respondents (98.3\%) are male. This is approximately consistent with IBGC (2011), which indicates $7.7 \%$ of women in board positions in Brazil. The results also point towards a sample of individuals in the 51-60 age group, accounting for $35.1 \%$ of the sample. The second largest age group is $41-50(32.4 \%)$. The entire sample has at least a university degree. Thirtyeight companies in the sample participate in the ISE index, and 36 are not part of this index of companies.

Companies considered large (with revenues over six hundred million reais) represented $41.8 \%$ of the sample. To classify companies' sector, we used the BM\&FBovespa standard. Of the 17 possible sectors, 11 are represented in the sample, the most relevant as follows: industrial (14.8\%), financial (12.2\%) and consumer and retail $(10.8 \%)$. Classification as to the level of governance followed the one presented by
BM\&FBovespa: Traditional market (44.6\% of sample companies), Level 1 (13.5\%), Level 2 (5.4\%) and New Market (36.5\%). The configuration of the axiological priorities of board members studied for the whole sample indicates a greater overall trend towards values referring to Universalism and Benevolence, and a smaller trend towards Power and Tradition. We can identify a general pattern sample in this diagnosis and in other studies with national publics. The sample data shows a Pearson correlation of 0.91 with Tamayo (2007), and of 0.79 with Calvosa, Sierra and Almeida (2011). That said, we move on to the answer to the research problem.

\subsection{Differences between ISE companies and all the other companies listed in BM\&FBovespa}

What are the differences, in terms of individual values, between the board members of companies with a pro-stakeholder corporate identity and other publicly traded companies in Brazil? Figure 3 shows the results pictorially.

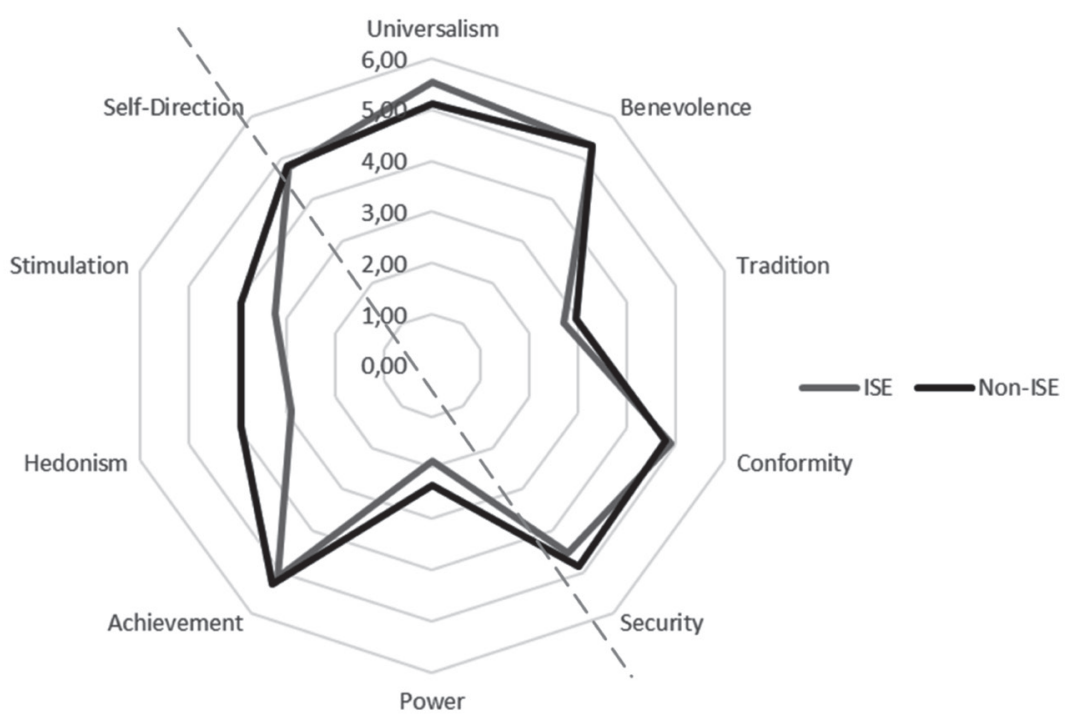

Figure 3. Circular structure of ISE companies $\times$ other companies

Source: The authors, 2016

The light gray line represents motivational types and values belonging to the group of board members from companies listed in the ISE index. The darker line illustrates the other companies. 
We can observe, on the left side of Figure 3 (where individualistic values are concentrated), that there is a visual difference between samples. Board members from companies included in ISE seem to have with less importance for this group of values, when compared to the sample of all other companies listed in BM\&FBovespa. This already allows us to preliminarily infer the rejection of the null hypothesis for $\mathrm{H}_{1}$ and, thus, to assert that values can be predictors of a prostakeholder or shareholder trend with respect to the individualism $\mathrm{x}$ collectivism agglutination.

This panoramic perception, however, must be statistically tested. We present, in Table 2, average differences between the two samples (ISE and others) with respect to two groups of values (individualistic and collectivist). Companies in the ISE index had an average individualism (considering the five motivational types to the left of the dashed line in Figure 3) equal to 3.65. The other companies obtained this value at 4.05 (a significant difference at 0.01). Regarding the set of collectivist values, however, there was no significant difference. This last result, nonetheless, is not surprising. This is because these guidelines do not make up a bipolar scale, but that "people are a bit of each, and, often, appropriate behavior is defined by the context and the immediate situation" (Gouveia, Andrade, Milfront, Queiroga \& Santos, 2003, p. 224).

Board members from companies belonging to the ISE index are less individualistic, which suggests that this is an important predictor of pro-stakeholder identity. Individualism "expresses a trend towards success, towards appreciation of one's own intimacy. In this type of orientation, the individual is above the groups in all aspects" (Gouveia et al., 2003, p. 225). We reject, therefore, the null hypothesis for $\mathrm{H}_{1}$, and confirm that board members from pro-stakeholder companies are less individualistic. In addition, however, we accepted the null hypothesis for $\mathrm{H}_{2}$, indicating that there is no evidence that the sample board members are different as to collectivism. It is worth remembering, in order to understand the above results, that the sample presented especially - in its entirety - a large presence of universalism and benevolence. This finding is consistent with other diagnoses in the Brazilian context, and highlights greater collectivism in general in national individual values, therefore preventing us from finding a greater number of collectivist particularly in ISE companies.

Table 2

Differences between the averages of two blocs of opposite motivational types ( $n=74)$

\begin{tabular}{lcccc}
\hline $\begin{array}{l}\text { Individualism-Collectivism } \\
\text { according to Schwartz }\end{array}$ & $\begin{array}{c}\text { Average - Listed in } \\
\text { Bovespa and ISE }\end{array}$ & $\begin{array}{c}\text { Average - Listed in } \\
\text { Bovespa, but not in ISE }\end{array}$ & $\begin{array}{c}\text { Mann-Whitney U } \\
\text { among motivational } \\
\text { types }\end{array}$ & $\begin{array}{c}\text { Significance Sig. (2 extremes) } \\
\text { among motivational types }\end{array}$ \\
\hline Individualism & $\mathbf{3 . 6 5}$ & $\mathbf{4 . 0 5}$ & $\mathbf{5 1 5 . 5}$ & $\mathbf{0 . 0 4 6 * *}$ \\
\hline Collectivism & 4.76 & 4.73 & 668.5 & 0.71 \\
\hline
\end{tabular}

** Significant at 0.01

The above data, moreover, partially complies with findings in literature. Adams et al. (2011) demonstrated the correlations transcribed in Table 1 , revealing significant relationships between individualism and shareholderism in the scope of individual decisions in an experimental situation. Mitchell, Agle and Wood (1997) also indicate that the values of managers as to individualism (self-interest) versus collectivism (self-sacrifice) moderate their relationships with stakeholders, by altering stakeholders' legitimacy. According to these authors, people with different values should, hypothetically, attribute different legitimacy to different publics. This finding stems from the perception, in literature, that the actions of an entity are considered legitimate if they are 
appropriate to the norms, values and beliefs of a social group (Suchman, 1995).

When comparing the two samples, not according to the individualism $\mathrm{x}$ collectivism agglutination, but to the 10 motivational types of Schwartz (2005), we observe that only types Stimulation and Hedonism statistically manifest themselves as different between the two groups of companies. These results offer answers to hypotheses $\mathrm{H}_{3}$ to $\mathrm{H}_{5}$. Thus, the results of this article are only in part aligned with the findings of
Adams et al. (2011) and with the hypotheses of the research. Stimulation, motivational type observed as more prevalent among non-ISE companies, is derived from the need for challenges in "exciting", "bold" and "varied lives" (Schwartz, 2005). Hedonism, also more manifest in companies which are not a priori pro-stakeholder oriented, refers to gratification through sensory pleasure and by avoidance of unpleasantness (Schwartz, 2005). Table 3 presents this discussion.

Table 3

Motivational Types in ISE and other listed companies $(n=74)$

\begin{tabular}{lcccccc}
\hline $\begin{array}{l}\text { Motivational } \\
\begin{array}{l}\text { Type according to } \\
\text { Schwartz }\end{array}\end{array}$ & $\begin{array}{c}\text { Individualism } \\
\text { (I) Collectivism } \\
\text { (C) according } \\
\text { to Schwartz }\end{array}$ & $\begin{array}{c}\text { Average }- \\
\text { Listed in } \\
\text { ISE }\end{array}$ & $\begin{array}{c}\text { Average }- \\
\text { Not listed in } \\
\text { ISE }\end{array}$ & $\begin{array}{c}\text { Mann-Whitney } \\
\text { U among } \\
\text { motivational } \\
\text { types }\end{array}$ & $\begin{array}{c}\text { Significance Sig. (2 } \\
\text { extremes) among } \\
\text { motivational types }\end{array}$ & $\begin{array}{c}\text { Correlations } \\
\text { found by Adams } \\
\text { et al.(2011) as to } \\
\text { Shareholderism }\end{array}$ \\
\hline Self-direction & I & 4.79 & 4.83 & 645.50 & 0.54 & Significant positive \\
Stimulation & I & 3.23 & 3.92 & 522.50 & $0.05^{*}$ & Significant positive \\
Hedonism & I & $\mathbf{2 . 8 9}$ & $\mathbf{3 . 9 2}$ & $\mathbf{4 9 7 . 0 0}$ & $\mathbf{0 . 0 2 8 ^ { * * }}$ & Non-significant \\
Achievement & $\mathrm{I}$ & 4.75 & 5.07 & 571.00 & 0.16 & Significant positive \\
Power & $\mathrm{I}$ & 1.87 & 2.36 & 592.00 & 0.24 & Significant positive \\
\hline Security & $\mathrm{C}$ & 4.52 & 4.85 & 565.50 & 0.14 & Significant positive \\
Conformity & $\mathrm{C}$ & 4.91 & 4.79 & 699.50 & 0.97 & Significant positive \\
Tradition & $\mathrm{C}$ & 2.71 & 2.94 & 600.00 & 0.27 & Significant positive \\
Benevolence & $\mathrm{C}$ & 5.31 & 5.30 & 684.00 & 0.84 & Significant positive \\
Universalism & $\mathrm{C}$ & 5.54 & 5.11 & 571.50 & 0.16 & Significant positive \\
\hline
\end{tabular}

** Significant at 0.01 and * Significant at 0.05

Although the results presented in Table 3 present certain convergence with the expected, it is not full (note that there is significance only in the two lines with *). Furthermore, as shown in the last column of Table 3, only the motivational type Stimulation showed complete correspondence with Adams et al. (2011). While those authors identified correlations between individual value and a pro-stakeholder or pro-shareholder trend in almost all motivational types, this article shows significance in only two of the motivational types of Schwartz's theory. This generates the answer that the null hypothesis (equality between samples) for $\mathrm{H}_{3}$ and $\mathrm{H}_{4}$ is rejected only for motivational types Stimulation and Hedonism. For the eight other motivational types, it is not possible to say that there are significant differences in motivational types considered individually.

Interestingly, Adams et al. (2011) did not reveal a significant correlation in Hedonism, while the data herein suggests that non-ISE companies' board members are more inclined towards seeking individual pleasure. Those authors evoke the Schumpeterian theory to indicate that businessmen do not seek individual pleasure in their business actions. According to this study, however, we reject the null hypothesis for $\mathrm{H}_{5}$, stating that companies that are not pro-stakeholders have more hedonistic board members. 
The reasons for this discrepancy are probably due, in the real organizational framework (a dimension added in this article), to interference from "non-laboratory" reality. We mention: (a) the stakeholder diversity observed in the reality of studied board members; (B) the heterogeneity of organizational cultures; (c) Different business sectors and their economic contexts and (d) dissimilar institutional environments. The work of Adams et al. (2011) aimed to capture only the individual level in an experimental context. Thus, while in a laboratory situation a high correlation between values and decision orientation can be observed, in empirical reality this correspondence was weaker, although present. According to Jo Hatch and Cunliffe (2005, p. 5), "human behavior is notoriously unpredictable, except under controlled conditions." Adams et al. (2011, p. 1339) understand this limitation by claiming that 'empirical research to study managers' support to shareholders or stakeholders should ideally examine their actual behavior", but they also stated that this research is virtually infeasible. Below, we discuss the above four items from literature as a way to suggest an initial debate to explain derivation between an individual decision and the actual context.

Stakeholders' different characteristics represent one of the major influencers of stakeholder management. The study of Adams et al. (2011) used vignettes containing dilemmas from actual legal cases. Little was informed, however, about the relative importance of these publics. In contrast, Mitchell, Agle and Wood (1997) argue that managers effectively pay attention to prominent publics - defined by these authors as the confluence of Power, Legitimacy and Urgency. The authors assert that literature is often simplistic, because in reality "managers cannot meet all real claims" (Mitchell, Agle \& Wood, 1997, p. 854). There is reason to believe, then, that the experimental situation applied by Adams et al. (2011) did not seize the "dynamic relationships and complex considerations" (Mitchell, Agle \& Wood, 1997, p. 854) that influence the prominence of an organization's stakeholders. It is worth remembering that these authors consider prominence as derived from the perception of businessmen: it refers to factors that are perceived by managers as gifts. In this sense, the answers attributed to the demands of stakeholders "are built over time, rather than an objective reality” (Agle, Mitchelll \& Sonnenfeld, 1999, p. 509).

The heterogeneity of organizational cultures also influences the profile of stakeholder management. March (1999) points out that individuals, in their complex organizational contexts, tend to make "appropriate" decisions. The logic of appropriateness is a perspective that sees human actions as partly driven by "exemplary" behavior rules facing a social group. Thus, extracting the organizational context of businessmen from decision should affect the divergence studied here. To strengthen this idea, Brickson (2005) states that the identity socially created by individuals and organizations forges relationships between companies and their stakeholders. The institutional environment similarly tends to modify the relationship of companies and their stakeholders. Scott and Meyer (1991) show that organizations are part of an environment from which they derive their regulation and their references for action. Depending on the specificities of the environment in which they operate, organizations are subject to dissimilar types and magnitudes of stakeholder influence. Abreu (2009) demonstrates, for example, that, in emerging countries, environmental regulations and stakeholder demands play a central role in raising commitment to environmental issues.

As well as the differences discussed above, there is another interesting discrepancy between the results of Adams et al. (2011) and those presented in this article: the study of those authors did not expose the connection between hedonism and stakeholder $\mathrm{x}$ shareholder decision. To them, interestingly, shareholderism showed no correlation with hedonism therefore motivations towards pleasure seem to play no part in building the company's position. They also claim that this finding would be noteworthy in light of Schumpeter's claim that businessmen's 
personal entrepreneurial interests are based on the quest for success, having little relationship with hedonistic incentives (Adams et al., 2011). The results of the study presented here suggest, however, a relationship between hedonism and pro-shareholder orientation. The sample companies that do not belong to the ISE index presented board members who were more inclined to seeking pleasure (see Table 3).

This finding may be discussed based on Freud, and may be reiterated by Stakeholder Theory. Indeed, in this respect, the possible reflection by this article is limited, indicating the need for further theoretical development of the issue. One reason for this bias is that the Schwartz SVI scale applied here offers only two assertions about hedonism (see Table 4 for a list of individually studied values). However, the results serve as a reminder of the importance of progress in addressing the Hedonism topic and its possible correlation with business profiles. How would the more or less hedonistic profile of main leaders influence their companies' trend towards shareholder or stakeholder value? Thus, how would leaders who advocate "a life full of delights" tend to lead organizations that emphasize shortterm financial gains? The questions above insert the particle "how" because, in this article, we have pointed out the presence of the relationship without, however, deepening the mechanisms through which this increased presence of hedonists in companies that are not stakeholderoriented occurs. The following paragraphs raise some possible explanations.

Addressing Hedonism compels us to bring to the debate theories stemmed from Psychology and its relationships with Organizational Theory. Freud (1930) indicates that the search for pleasure tends to impel individuals to the shortest paths in their search for pleasure and avoidance of displeasure. Freudian work called this element the "principle of pleasure." However, the same author conceived the idea of the "principle of reality" which, contrary to other findings, asserts that, to obtain certain pleasures, it is necessary to differentiate them because of the group culture within which one lives (Drago, 1992). According to Freud, if human beings had full freedom to pursue their natural objectives, there would be no lasting social compatibility and preservation. Thus, "immediate satisfaction becomes delayed satisfaction" (Drago, 1992, p. 60) and this changes "not only instinctive desires as well as instinctive values" (ibid, p. 60). This finding creates doubts about the extent to which reality perceived by active managers in companies with pluralist models would cause smaller stimulus to shortterm gratification.

There are indications, also in the Stakeholder Theory, that orientation towards reciprocity-based relationships tend to - especially in the long-term - add value to companies (Harrison et al., 2010). Due to the correspondence between the dichotomy of looking for short or long-term results and the principles of Freud's theory of pleasure, we conjecture, in this article, that there are relationships between hedonism and pro-shareholder decisions. The results presented here allow us only to demonstrate this possible relationship. In Adams et al. (2011), perception of pleasure was not observed by respondents.

The previous discussion aimed to compare the results between ISE and non-ISE samples at the level of motivational types. Thus, answers to the research hypotheses are already available. We will now offer a brief description of the 60 individual values proposed by Schwartz (2005), so as strengthen and detail these answers. As seen in Table 4, only in 18 distinct values did we identify significant inequities between ISE and non-ISE companies. In certain values, expected directions are different from expected.

Considering a 0,1 significance level, we also observe that two of the values relating to type Self-direction (independence and self-respect) are significantly more present in companies not listed in ISE. On the other hand, stakeholder-oriented companies pointed towards the axiological priority of freedom. In Achievement, we observed that board members from companies not geared towards non-financial publics indicated that being "influential" is more important - a fact that also explains the higher incidence of individualism in this sample. 
Table 4

Statistics concerning specific values

\begin{tabular}{|c|c|c|c|c|c|}
\hline Motivational Type & Values & ISE & Non-ISE & M. Whitney U & Sig. \\
\hline \multirow[t]{6}{*}{ Self-direction } & Curiosity & 6.05 & 5.37 & 580.5 & 0.17 \\
\hline & Creativity & 5.84 & 5.55 & 603 & 0.27 \\
\hline & Freedom & 6.16 & 5.55 & 535.5 & $0.06^{*}$ \\
\hline & Self-directed & 5.62 & 5.24 & 653.5 & 0.59 \\
\hline & Independent & 1.51 & 2.68 & 531.5 & $0.07^{*}$ \\
\hline & Self-respect & 3.54 & 4.58 & 520.5 & $0.05^{*}$ \\
\hline \multirow[t]{3}{*}{ Stimulation } & Bold & 4.19 & 4.92 & 519 & $0.047^{* *}$ \\
\hline & Varied life & 1.78 & 1.74 & 657 & 0.62 \\
\hline & Exciting life & 3.73 & 5.11 & 481 & $0.017^{* *}$ \\
\hline \multirow[t]{2}{*}{ Hedonism } & Pleasure & 2.49 & 3.32 & 537 & $0.08^{*}$ \\
\hline & Life of pleasure & 3.30 & 4.53 & 501 & $0.03^{* *}$ \\
\hline \multirow[t]{6}{*}{ Achievement } & Successful & 6.14 & 5.87 & 670.5 & 0.71 \\
\hline & Capable & 4.95 & 5.13 & 666.5 & 0.69 \\
\hline & Ambitious & 5.97 & 6.16 & 621 & 0.36 \\
\hline & Influential & 2.81 & 3.89 & 501.5 & $0.03^{* *}$ \\
\hline & Intelligent & 4.24 & 4.47 & 693 & 0.91 \\
\hline & Smart & 4.38 & 4.89 & 560.5 & 0.12 \\
\hline \multirow[t]{6}{*}{ Power } & Social power & 1.41 & 1.95 & 635 & 0.47 \\
\hline & Authority & 1.27 & 1.47 & 669 & 0.71 \\
\hline & Riches & 1.97 & 2.74 & 530.5 & $0.06^{*}$ \\
\hline & Public image & 1.84 & 2.11 & 690 & 0.89 \\
\hline & Vanity & 2.43 & 2.95 & 609.5 & 0.32 \\
\hline & Social image & 2.32 & 2.92 & 613 & 0.34 \\
\hline \multirow{7}{*}{ Security } & Clean & 4.22 & 4.92 & 542.00 & $0.08^{*}$ \\
\hline & National security & 1.89 & 2.84 & 546.00 & $0.09^{*}$ \\
\hline & Retribution of values & 6.30 & 5.76 & 563.5 & 0.10 \\
\hline & Social order & 3.19 & 3.87 & 626 & 0.41 \\
\hline & Family security & 6.49 & 6.11 & 613 & 0.27 \\
\hline & Sense of belonging & 4.49 & 4.84 & 636.5 & 0.47 \\
\hline & Healthy & 5.08 & 5.63 & 622.5 & 0.38 \\
\hline \multirow[t]{4}{*}{ Conformity } & Obedient & 3.78 & 3.92 & 675.5 & 0.77 \\
\hline & Respect for the elderly & 5.57 & 5.58 & 677 & 0.77 \\
\hline & Politeness & 5.95 & 5.26 & 553.00 & $0.098^{*}$ \\
\hline & Self-disciplined & 4.32 & 4.39 & 684 & 0.84 \\
\hline \multirow[t]{6}{*}{ Tradition } & Conscious of limits & 5.68 & 5.08 & 595 & 0.24 \\
\hline & Devoted & 1.73 & 2.45 & 583.5 & 0.20 \\
\hline & Humble & 4.05 & 4.08 & 695.5 & 0.94 \\
\hline & Respect for tradition & 1.30 & 2.50 & 490.5 & $0.022^{* *}$ \\
\hline & Moderate & 0.03 & 0.45 & 626 & 0.39 \\
\hline & Privacy & 3.49 & 3.11 & 632.5 & 0.45 \\
\hline \multirow[t]{10}{*}{ Benevolence } & Helpful & 4.86 & 5.16 & 592 & 0.23 \\
\hline & Honest & 4.86 & 5.24 & 587.5 & 0.21 \\
\hline & Forgiving indulgence & 4.76 & 4.71 & 693 & 0.91 \\
\hline & Loyal & 5.51 & 5.68 & 657 & 0.61 \\
\hline & Responsible & 6.30 & 6.00 & 592 & 0.19 \\
\hline & Work & 5.89 & 5.58 & 589 & 0.21 \\
\hline & Spiritual life & 2.73 & 3.50 & 582 & 0.20 \\
\hline & True friendship & 6.30 & 5.53 & 544.00 & $0.07^{*}$ \\
\hline & Mature love & 6.00 & 5.84 & 652.5 & 0.57 \\
\hline & Meaning of life & 5.89 & 5.74 & 617.5 & 0.32 \\
\hline Universalism & The environment & 6.05 & 5.47 & 540.50 & $0.07^{*}$ \\
\hline
\end{tabular}




\begin{tabular}{|c|c|c|c|c|c|}
\hline Motivational Type & Values & ISE & Non-ISE & M. Whitney U & Sig. \\
\hline & Unity with nature & 4.92 & 4.21 & 512 & $0.039^{* *}$ \\
\hline & A world of beauty & 4.89 & 3.76 & 429.5 & $0.003^{* *}$ \\
\hline & $\mathrm{Na}$ open mind & 5.57 & 5.16 & 640.5 & 0.49 \\
\hline & Social justice & 5.46 & 5.47 & 685 & 0.84 \\
\hline & Wisdom & 6.00 & 5.66 & 644 & 0.51 \\
\hline & Equality & 5.11 & 4.82 & 660 & 0.64 \\
\hline & World peace & 5.41 & 4.63 & 532.00 & $0.06^{*}$ \\
\hline & Dreamer & 6.14 & 5.84 & 626 & 0.38 \\
\hline & Inner harmony & 5.89 & 6.11 & 591 & 0.20 \\
\hline
\end{tabular}

* Significant at $0.1{ }^{* *}$ Significant at 0.05 - Source: The authors, 2016

Note also that owning "riches" (wealth) is more intense in companies that are not stakeholderoriented. Interestingly, in motivational type Security, the only values that showed differences were "clean" and "national security", and that these differences were opposite to the expected. It is worth remembering that this motivational type is the first collectivist one in the Schwartz circle and, therefore, we could understand it as transitory. This "inverted" phenomenon also occurs with the value "respect for tradition." This also appeared more intense in non- stakeholderoriented organizations. Board members from non-ISE companies, therefore, seem to be more conservative. Table 5 summarizes the findings.

\section{Table 5}

\section{Summary of findings}

\begin{tabular}{|c|c|c|}
\hline Research Hypotheses & Answers & Observations \\
\hline $\begin{array}{l}\text { Board members from stakeholder-oriented } \\
\text { companies present significantly lower } \\
\text { individualism than those from other companies } \\
\left(\mathrm{H}_{1}\right)\end{array}$ & $\begin{array}{l}\text { The null hypothesis is rejected (equally } \\
\text { among averages), confirming that board } \\
\text { members from stakeholder-oriented } \\
\text { companies are more individualistic }\end{array}$ & $\begin{array}{l}\text { ISE board members indicated less } \\
\text { importance to a life of pleasure and the } \\
\text { need for social influence }\end{array}$ \\
\hline $\begin{array}{l}\text { Board members from stakeholder-oriented } \\
\text { companies present significantly higher collectivism } \\
\text { than those from other companies }\left(\mathrm{H}_{2}\right)\end{array}$ & $\begin{array}{l}\text { No opposition between the concepts } \\
\text { of individualism and collectivism was } \\
\text { demonstrated. } \\
\text { The null hypothesis is accepted }\end{array}$ & $\begin{array}{l}\text { Although collectivism was shown to be } \\
\text { equivalent, non-ISE board members } \\
\text { demonstrated made conservative values } \\
\text { a priority }\end{array}$ \\
\hline $\begin{array}{l}\text { Board members from stakeholder-oriented } \\
\text { companies present motivational types Self- } \\
\text { Direction, Stimulation, Achievement and } \\
\text { Power significantly lower than those from other } \\
\text { companies }\left(\mathrm{H}_{3}\right)\end{array}$ & $\begin{array}{l}\text { The null hypothesis is rejected only for } \\
\text { motivational types Stimulation and } \\
\text { Hedonism }\end{array}$ & $\begin{array}{l}\text { Here there is disagreement with the } \\
\text { findings of Adams et al. (2011). Those } \\
\text { authors found correlations in nine of the } \\
\text { ten MTs }\end{array}$ \\
\hline $\begin{array}{l}\text { Board members from stakeholder-oriented } \\
\text { companies (in the ISE index) present motivational } \\
\text { types Security, conformity, Tradition, Benevolence } \\
\text { and Universalism significantly higher than those } \\
\text { from other companies }\left(\mathrm{H}_{4}\right)\end{array}$ & $\begin{array}{l}\text { The null hypothesis is rejected for all } \\
\text { collectivist motivational types }\end{array}$ & $\begin{array}{l}\text { This rejection is partly explained by the } \\
\text { higher incidence, in the whole sample, } \\
\text { of types prone to universalism and } \\
\text { benevolence }\end{array}$ \\
\hline $\begin{array}{l}\text { Board members from stakeholder-oriented } \\
\text { companies (in the ISE index) present motivational } \\
\text { type Hedonism equivalent to the board members } \\
\text { of other companies }\left(\mathrm{H}_{5}\right)\end{array}$ & $\begin{array}{l}\text { The null hypothesis is rejected, and } \\
\text { hedonistic priorities are perceived } \\
\text { among board members from non-ISE } \\
\text { companies }\end{array}$ & $\begin{array}{l}\text { This finding is the contradictory with } \\
\text { respect to the work of Adams et al. } \\
\text { (2011) }\end{array}$ \\
\hline
\end{tabular}

Source: The authors, 2016 


\section{Conclusions, limits, and future directions}

This article aimed to evaluate the relationship between individual values and corporate identity in favor of shareholders or other stakeholders. Previous research - Adams et al. (2011) - revealed strong correlations between the above values and individual decisions by directors. Brickson (2005) indicates that the identity of a company is strongly related to its relationships with stakeholders, and that this orientation can vary between individualistic and collectivist. As shown in Table 5, the findings of this article indicate only partial convergence with the previous study.

If, on one hand, the predictive power of individual values may indicate board members' decision-making trends, on the other, regulation, culture and the environment tend to exert pressure on individuals. From a practical point of view, this seemingly dynamic process indicates that individuals tend to look for positions that are more closely aligned with their beliefs, but only when the options are available. The smaller propensity towards individualism by board members from companies that voluntarily declare themselves as more concerned with other stakeholders allows us to suggest that the context and the group, as pointed out by March (1999), do in fact interfere in the behavior of individuals. This finding further reinforces that the regulatory environment does have the power to influence (Brickson, 2005), if not individual values, the behavior of those who are part of a given organization.

The motivational types that characterize individualism are less pronounced in board members who work for stakeholder-oriented companies. It is noteworthy, however, that motivational types Hedonism and Stimulation are worth mentioning, since they are related to sensory satisfaction. These motivational types, sometimes forgotten by organizational studies, have shown that, beyond the power, ambition and self-determination of businessmen, innermost motivations are deeply linked to their decision-making processes. In contrast, we must highlight the similar importance given by both groups to collectivism. These findings are in line with national values, leading us to realize that predominant cultural traits are not always decisive to decision-making.

Companies rely on individuals to promote their values and cultures; the results show an opposite trend to the traditional isomorphism of companies, indicating that, even though they are part of a national culture, there may be several corporate identities, raised by a variety of controlling shareholders, not necessarily converging to dominant culture - also indicating that many other factors influence business practices, beyond context and rules, and, therefore, are a matter of business options and choice. This argument goes against traditional common sense, as well as expands and brings additional responsibilities to organizations. We suggest that these boundaries between the internal and external environments of organizations which make them unique even though they are part of a given culture - can be the individual values of their leaders.

Although the findings do not allow us to establish causal relationships, the practical implications of this material are significant. Companies that wish to enhance stakeholderoriented organizational identities should measure board members' and other directors' values to thus maximize the likelihood of this identity being realized. Leaders who are more intensely in agreement with the values of an organization tend to be more committed to its interests (Boivie et al., 2011). Although this article has not pointed out relationships that are as strong as those observed by Adams et al. (2011), the imperative of searching for adhesion between individual values and organizational identity remains.

Despite its contributions, this research does have limitations. In addition to the limitations already exposed throughout the text, we recognize that the research findings are still circumscribed 
to a small sample, and by particular methods: the Schwartz scale and the adoption of ISE criterion to infer pro-stakeholder orientation. Furthermore, we believe that the theoretical discussion presented has gaps, due to its complexity and amplitude. Specific research concerning values and specific topics can offer greater depth.

Thus, the results of this research point to other possible investigations, such as: (i) assessing whether individual values of board members considered independent present different axiological priorities from other board members' values, (ii) studying whether board members working in different institutional environments also present different axiological priorities, (iii) deepening the theoretical and empirical discussion of Hedonism's role in building organizational orientation, and (iv) developing qualitative work, such as case studies, which penetrate the meanings, contexts and nuances of the relationships between values and orientations presented in this material. The issue, in short, is complex. The debate goes on.

\section{References}

Abreu, M. C. S. (2009). How to define an environmental policy to improve corporate sustainability in developing countries. Business Strategy and the Environment.18, 542-546.

Adams, R. B., Licht, A. N., \& Sagiv, L. (2011). Shareholders and stakeholders: how do board members decide? Strategic Management Journal. 32, 1331-1355.

Agle, B.R., Mitchelll, R.K., \& Sonnenfeld, J.A. (1999). Who matters to CEOs? An investigation of stakeholder attributes and salience, corporate performance, and CEO Values. Academy of Management Journal. 42 (5), 507-525.

Bartlett, J, Mc Donald, P. \& Pini, B. (2015). Identity orientation and stakeholder engagement - the corporatisation of elite schools. Journal of Public Affairs, 15(2), 201-209.
Bm\&fbovespa (2015). Índice de sustentabilidade empresarial-ISE. Recuperated on September 1, 2015, from: http://www.bovespa.com.br.

Boaventura, J. M. G., Cardoso, F. R., Silva, E. S., \& Silva, R. S. (2009). Teoria dos stakeholders e teoria da firma: um estudo sobre a hierarquizaçáo das funçôes-objetivo em empresas brasileiras. Revista Brasileira de Gestão de Negócios.11(1), 289-307.

Boivie, S., Lange, D., Mc Donald, M. L., \& Westphal, J. D. (2011). Me or we: The effects of CEO organizational identification on agency costs. Academy of Management Journal, 54, 551-576.

Bosse D. A., Phillips R.A., \& Harrison J.S. (2009). Stakeholders, reciprocity, and firm performance. Strategic Management Journal. 30(4), 447-456.

Brickson, S. L. (2005). Organizational identity orientation: forging a link between organizational identity and organizations' relations with stakeholders. Administrative Science Quartely. 50, 576-609.

Bridoux, F., \& Stoelhorst, J. W. (2014). Microfoundations for stakeholder theory: managing stakeholders with heterogeneous motives. Strategic Management Journal. 35, $107-$ 125.

Bruére, A. J., Mendes-da-Silva, W., \& Santos, J. F. dos (2007). Aspectos da governança corporativa de empresas listadas na bovespa: um estudo exploratório sobre a composição e perfil dos Conselhos de Administração. Revista de Administração e Contabilidade. Unisinos. 4(2), 149-159.

Calvosa, M. V., Serra, F. A., \& Almeida, M. I. (2011). Quais são as prioridades axiológicas dos lideres empresariais? Análise dos seus valores pessoais a partir do inventário de valores SVS de Schwartz. Encontro de Gestão de Pessoas e Relaçóes de Trabalho. João Pessoa, PA, Brasil, Ex: 24 
Clarke, T. (1998). The shareholders corporation: a business philosophy for the information age. Long Range Planning, 31(2), 182-194.

Davis, J. H., Schoorman, D. F., \& Donaldson, L. (1997). Toward a stewardship theory of management. Academy of Management Review, $22,20-47$.

Dollinger, S .J., Burke, P.A. \& Gump, N.W. (2007). Creativity and values. Creativity Research Journal, 19, 91-103.

Drago, P. A. (1992). Teoria crítica e teoria das organizações. Revista de Administração de Empresas. São Paulo, 32(2), 58-64.

Fávero, L. P., Belfiore, P., Takamatsu, T. R., \& Suzart, J. A. (2009). Métodos quantitativos com stata. Rio de Janeiro: Elsevier.

Fiss, P. C., \& Zajac, E. J. (2004). The diffusion of ideas over contested terrain: the (non)adoption of a shareholder value orientation among german firms. Administrative Science Quarterly, 49, 501-534.

Freeman, R. E. (1984). Strategic management: a stakeholder approach. Nova Iorque. Cambridge University Press.

Freeman, R. E \& Phillips, R. A. (2002). Stakeholder theory: a libertarian defense. Business Ethics Quartely, 13, 331-349.

Freud, S. (1930). Civilization and its discontents. Nova Iorque. The Standard Edition.

Friedman, M. (1962). Capitalism and freedom (2a ed.). University of Chicago Press.

Gouveia, V. V., Andrade, J. M., Milfont, T. L. Queiroga, F., \& Santos, W. S. (2003). Dimensões normativas do individualismo e coletivismo: é suficiente a dicotomia pessoal vs. social? Psicologia: Reflexão e Crítica, 16(2), 223-234.

Guerra, S. M. (2009). Os papéis do conselho de administração em empresas listadas no Brasil.
2009. Dissertação (Mestrado em Administração) - Faculdade de Economia, Administração e Contabilidade, Universidade de São Paulo, São Paulo, Brasil.

Harrison, J. S., Bosse, D. A., \& Philips, R. A. (2010). Managing for stakeholders, stakeholder utility functions and competitive advantage. Strategic Management Journal, 31, 58-74.

Harrison, J. S., Freeman, R. E. \& Abreu, M. C. S. (2015) Stakeholder Theory as an ethical approach to effective management: Applying the theory to multiple contexts. Revista Brasileira de Gestão de Negócios, 17(55), Special Edition, 858-869.

Hiller, N. J., \& Hambrick, D. C. (2005). Conceptualizing executive hubris: the role of (hypercore) self-evaluations in strategic decision-making. Strategic Management Journal, 26, 297-319.

Hofstede, G. (1980). Cultural consequences: international differences in work related values. Beverly Hills: Sage.

IBGC - Instituto Brasileiro de Governança Corporativa (2011). Relatório de mulheres na administração das empresas brasileiras listadas - 2010 e 2011. Recuperated on May 18, 2016, from http://www.ibgc.org.br/userfiles/files/ Mulheres_no_Conselho.pdf

Jensen, M. C., (2001). Value maximization, stakeholder theory and the corporate objective function. European Financial Management, 7 (3), 297-317.

Jo Hatch, M., \& Cunliffe, A. (2005). Organization theory: modern, symbolic and postmodern perspectives. Oxford: Oxford University Press.

Jones, T. M., Felps, W., \& Bigley, G. A. (2007). Ethical theory and stakeholder-related decisions: The role of stakeholder culture. Academy of Management Review, 32(1), 137-155.

Keeney, R. L., (1992). Value-focused thinking: a path to creative decision making. Cambridge, MA: Harvard University Press. 
Kilmann, R., Saxton, M., \& Serpa, R. (1986). Gaining control of the corporate culture. São Francisco: Jossey-Bass.

Laplume, A. O., Sonpar, K., \& Litz, R. A. (2008). Stakeholder theory: reviewing a theory that moves us. Journal of Management, 34, 1152-1189.

Lee W.N. \& Choi S. M. (2005). The role of horizontal and vertical individualism and collectivism in online consumers' response toward persuasive communication on the web. Journal of Computer-Mediated Communication, 11(1), 280-298.

March, J. G. (1999). The pursuit of organizational intelligence. Oxford: Blackwell.

Margolis, J. D., \& Walsh, J. P. (2003). Misery loves companies: rethinking social initiatives by business. Administrative Science Quarterly, 48, 268-305.

Meglino, B. M., \& Ravlin, E. C. (1998). Individual values in organizations: concepts, controversies, and research. Journal of Management, 24(3), 353-389.

Mitchelll R. K., Agle B. R., \& Wood D. J. (1997). Toward a theory of stakeholder identification and salience: defining the principle of who and what really counts. Academy of Management Review, 22, 853-886.

Puncheva, P. (2008). The role of corporate reputation in the Stakeholder decision-making process. Academy of Magament Review. v. 32. n.3. p. $946-967$

Rokeach, M. (1973). The nature of human values. Free Press. Nova Iorque.

Ringov, D., \& Zollo, M. (2007). Corporate responsibility from a socio-institutional perspective: the impact of national culture on corporate social performance. Corporate Governance, 7(4), 476-485.
Sagiv, L., Sverdlik, N., \& Schwartz, S. H. (2011). To compete or to cooperate? Values'impact on perception and action in social dilemma games. European Journal of Social Psychology, 41, 64-77.

Saito, R., \& Dutra, M. G. L. (2002). Conselhos de administração: análise de sua composição em um conjunto de companhias abertas brasileiras. Revista de Administração Contemporânea, 6(2), 9-27.

Schwartz, S. H. (1992). Universals in the content and structure of values: theory and empirical tests in 20 countries. New York: Zanna.

Schwartz, S. H. (1994). Are there universal aspects in the structure and contents of human values? Journal of Social Issues, 50(4), 19-45.

Schwartz, S. H. (2005). Theory of cultural value orientations: explication and applications. Comparative Sociology, 5(2), 137-182.

Scott, W. R., \& Meyer, J. W. (1991). The organization of societal sectors: propositions and early evidence. In: Powell, W. W. \& Dimaggio, P. J. (Eds). The new institutionalism in organizational analysis. Chicago: University of Chicago Press.

Suchman, M. C. (1995). Managing legitimacy: strategic and institucional approaches. Academy of Management Review, 20, 571-610.

Sverdlik, N., \& Oreg, S. (2009). Personal values and conflicting motivational forces in the context of imposed change. Journal of Personality, 77, 1437-1466.

Tamayo, A. (2007). Contribuições ao estudo dos valores pessoais, laborais e organizacionais. Psicologia: Teoria e Pesquisa, 23, 63-70.

Tamayo, A., \& Porto, J. B. (2005). Valores e Comportamentos nas Organizaçóes. Petrópolis: Vozes.

Triandis, H. C. (1995). Individualism and collectivism. Boulder, CO: Westview Press. 
Triandis H. C. \& Gelfand M. J. (1998). Converging measurement of horizontal and vertical individualism and collectivism. Journal of Personality and Social Psychology, 74(1), 118-128.

Verplanken, B., \& Holland, R. W. (2002). Motivated decision making: effects of activation and self-centrality of values on choices and behavior. Journal of Personality and Social Psychology, 2, 434-447.

Weick, K. (1999). That's moving: theories that matter. Journal of Management Inquiry, 8, 134-142.

\section{About the authors:}

1. Edson Ricardo Barbero, PhD in Business Administration by the Faculty of Economics, Business Administration and Accounting of the University of Sáo Paulo (FEA-USP). Master Program Professor at the Álvares Penteado Foundation School of Commerce (Fecap), Brazil. E-mail: ebarbero@fecap.br.

2. Marcello Marchiano, Master in Business by Álvares Penteado Foundation School of Commerce (Fecap), PhD. Candidate from Nove de Julho University, Brazil. E-mail: m.marchiano@uol.com.br.

\section{Contributions by each author:}

\begin{tabular}{lcc}
\hline Contribution & Edson Ricardo Barbero & Marcello Marchiano \\
\hline 1. Definition of research problem & $\sqrt{ }$ & $\sqrt{ }$ \\
2. Development of hypotheses or research questions (empirical studies) & $\sqrt{ }$ & $\sqrt{ }$ \\
3. Development of theoretical propositions (theoretical work) & $\sqrt{ }$ & $\sqrt{ }$ \\
4. Theoretical foundation/Literature review & $\sqrt{ }$ & $\sqrt{ }$ \\
5. Definition of methodological procedures & & $\sqrt{ }$ \\
6. Data collection & & $\sqrt{ }$ \\
7. Statistical analysis & & $\sqrt{ }$ \\
8. Analysis and interpretation of data & $\sqrt{ }$ \\
9. Critical revision of the manuscript & $\sqrt{ }$ \\
10. Manuscript writing & & $\sqrt{ }$ \\
\end{tabular}

